\title{
The Impact of Institutional Arrangements on Educational Efficiency
}

\author{
Trevor C. Collier ${ }^{*}$ \\ Department of Economics and Finance, University of Dayton, 300 College Park, Dayton, OH, 45469, USA
}

\begin{abstract}
Per pupil expenditures on education in the United States have grown immensely in recent decades, yet student achievement has been stagnant. An abundance of research has sought to solve this enigma, much of it centered on the incentive structure facing administrators. Some recent papers use TIMSS data to analyze the relationship between institutional arrangements - that typically do not vary within a single country - and student achievement. Similarly, we utilize TIMSS 1999 to determine if there is an indirect relationship between institutional arrangements and student achievement, via a relationship with school efficiency. Our results show that the specified link between institutional arrangements and student achievement (direct or indirect) is important in certain instances and confirm evidence found in previous research that certain arrangements are beneficial or detrimental to student achievement, regardless of the specification chosen.
\end{abstract}

Keywords: Student achievement, institutions, efficiency.

\section{INTRODUCTION}

Real per pupil expenditures in the U.S. increased from $\$ 2,670$ in the $1960-1961$ school-year to $\$ 9,266$ in the 2004 2005 school-year (figures are in constant 2006-2007 U.S. dollars), while pupil-teacher ratios fell from 27.4 in 1960 to 15.4 in 2005 [1]. Obviously policymakers in this country believe that increased educational funding will lead to increased school quality (student achievement). Alas, student achievement has not shown any improvement over the past several decades $[2,3]$. Research on the impact of so-called school inputs (i.e. teacher education, teacher salaries, etc.) has resulted in scant evidence of a link between these inputs and student achievement. Hanushek [4] sums up this literature by saying, "A wide range of analyses indicate that overall resource policies have not led to discernible improvements in student performance."

In response to the lack of a significant relationship between school resources and student performance, many researchers have directed their attention toward the incentives faced by school teachers and administrators. A common conclusion is that schools are plagued by inefficiency, and that inefficiency will persist until the incentive structure is altered [4-6]. Studies analyzing inefficiency in public schools have been able to locate the missing relationship between school resources and student performance [7, 8]. Additionally, Collier and Millimet [9] find some evidence to support the notion that increased competition leads to increased efficiency in public schools, but only in districts that operate in financially flexible environments. Duncombe et al. [10] use Data Envelopment Analysis (DEA) and report lower levels of cost efficiency in

\footnotetext{
*Address correspondence to this author at the Department of Economics and Finance, University of Dayton, 300 College Park, Dayton, OH, 45469, USA; Tel: 937-229-5302; Fax: 937-229-2477;

E-mail: collier@udayton.edu
}

districts facing greater competition as measured by private school enrollment.

The large majority of the research on education focuses on data collected within the United States. There are plenty of exceptions to this rule $[11,12]$; however, even less research has included data collected from multiple countries. A number of recent papers have used the Trends in International Mathematics and Science Study (TIMSS), an international project that collects data every four years on: student achievement scores, family background, class, school, and country characteristics $[3,9,13-15]$.

Woessman [15], in a seminal paper using data from TIMSS 1995, finds that the following institutional characteristics have significant positive impacts on student achievement: central examinations, centralized control mechanisms in curricular and budgetary affairs, school autonomy in process and personnel decisions, individual teachers having both incentives and powers to select appropriate teaching methods, limited influence of teachers' unions, scrutiny of students' educational performance, encouragement of parents to take interest in teaching matters, and intermediate level of administration performing administrative tasks and educational funding, and competition from privately managed schools. His research shows that a combination of all positive influencing institutional arrangements leads to a test-score increase of almost two standard deviations (ceteris paribus) over the least conducive arrangement.

Similarly, Collier and Millimet [9] take a distributional approach, testing the institutional arrangements using quantile treatment effects, and find that many of the conditional mean results in Woessman [15] do not hold for the entire distribution of student test scores.

The drawback to Collier and Millimet [9] and Woessman [15] is that they allow only for a direct relationship between the institutional characteristics and student test scores. From 
a theoretical standpoint, it is more likely that the institutional arrangements have an indirect relationship with student achievement. Following this same logic, Dustmann et al. [16] analyzed the impact of class size in secondary school on earnings later in life using data from England. While previous studies have failed to uncover any relationship between measures of school quality and subsequent labor market outcomes, the authors did find a positive impact by specifying the exact linkage. Specifically, the authors hypothesized that secondary school class size affects the probability of attending college and college attendance affects subsequent earnings. The data supported the hypothesis. Thus, the authors were able to establish a relationship between secondary school quality and earnings through the utilization of a two-step modeling approach.

This paper adds to the literature in two ways: (i) provides another analysis using cross-country data and (ii) analyzes the way in which institutional factors enter the educational production function (i.e. directly or indirectly via an association with efficiency). This relationship will be tested by estimating efficiency at the school level; and then estimating the relationship, if any, of the institutional arrangements with this efficiency. These results are compared to the results using a standard ordinary least squares model (OLS) with the institutional arrangements included as regressors.

Many of the institutional arrangements tested here are found to have different coefficient estimates across the two models utilized. However, in none of these instances do the signs of the coefficients differ and hold statistical significance. The differences that do exist could be an indication that the true relationship between these institutional arrangements and student achievement is actually an indirect one; via a relationship with school efficiency. These differences could also result simply from a mis-specification of either model. Further research is needed to confirm the appropriate relationship.

This paper does confirm the results of some of the previous research on institutional arrangements in education. Consistent with Collier and Millimet [9] and Woessman [15], we find that school autonomy in purchasing supplies has a positive relationship with student achievement and efficiency, and that teachers' unions having a large influence on curriculum is associated with lower levels of student achievement and school efficiency $[9,15]$.

The remainder of this paper is organized as the following. Section 2 describes the estimation techniques used herein. Section 3 gives an overview of the data. Section 4 discusses the results. Section 5 concludes.

\section{METHODOLOGY}

A two-stage model will be used to test whether the institutional arrangements discussed in this paper have any association with efficiency in schools. The first-stage entails estimation of school level efficiency; the second-stage analyzes the relationships between institutional characteristics and efficiency. Each stage is discussed in turn.

\subsection{Efficiency Estimation}

The panel data production function estimator of Schmidt and Sickles [17] is used to estimate the school level efficiency. The panel data production function estimator is very appealing, given that it reduces to the standard fixed effects linear regression model. Alternative approaches exist, including nonparametric Data Envelopment Analysis (DEA) and maximum likelihood stochastic frontier models. DEA models are criticized for their inability to account for stochastic error. Maximum likelihood models assume a parametric distribution for the inefficiency term (usually half-normal or exponential), and require the inefficiency to be independent across observations, as well as uncorrelated with the choice of inputs. Monte Carlo simulations have shown the maximum likelihood models to be outperformed by both DEA and the panel data production function estimator. Additionally, the assumption of an inefficiency term that is uncorrelated with the choice of inputs could be problematic in answering the research question of this paper.

The production function for student achievement can be written as

$\mathrm{y}_{\text {isk }}=\alpha+\mathrm{x}_{\text {isk }} \beta-\mathrm{u}_{\mathrm{sk}}+\varepsilon_{\text {isk }}$

where $y_{\text {isk }}$ is a measure of student achievement for student $i$ in school $s$ in country $k, x_{\text {isk }}$ is a vector of inputs, $u_{\text {sk }}$ is the level of technical inefficiency in school $\mathrm{s}$ in country $\mathrm{k}$, and $\varepsilon_{\text {isk }}$ represents purely idiosyncratic shocks which are uncorrelated with the choice of inputs. Consistent with the interpretation of $u$ as an inefficiency term, it is assumed that $\mathrm{u}_{\mathrm{sk}}>0$ for all $\mathrm{s}, \mathrm{k}$.

Grouping the intercept and the technical inefficiency term, equation (1) may be re-written as

$\begin{aligned} \mathrm{y}_{\text {isk }} & =\left(\alpha-\mathrm{u}_{\mathrm{sk}}\right)+\mathrm{x}_{\mathrm{isk}} \beta+\varepsilon_{\text {isk }} \\ & =\alpha_{\text {sk }}+\mathrm{x}_{\text {isk }} \beta+\varepsilon_{\text {isk }}\end{aligned}$

Given the above assumption concerning the error term, $\varepsilon$, equation (2) may be estimated using the standard fixed effects ('within') estimator. Estimates of $\mathrm{u}_{\mathrm{sk}}$ that are strictly non-negative are then given by the deviation between each school-specific intercept and the maximum intercept:

$\hat{u}_{s k}=\max _{s}\left\{\hat{\alpha}_{s k}\right\}-\hat{\alpha}_{s k} \geq 0$

By construction, the most efficient class is deemed completely efficient. The technical efficiency measure used in the second-stage analysis (discussed in the next section) is defined as $\hat{t}_{s k}=\exp \left(-\hat{u}_{s k}\right)$, which is bound by zero and unity. As shown in Schmidt and Sickles [17], $\hat{t e}_{s k}$ provides a consistent estimate of te $\mathrm{s}_{\mathrm{sk}}$ as $\mathrm{N}, \mathrm{T} \rightarrow \infty$. In the present context $\mathrm{N}$ refers to the number of schools, and $\mathrm{T}$ refers to the number of students in each school.

Two potential drawbacks to the Schmidt and Sickles [17] approach have been documented in the literature, and are worth mentioning. First, technical inefficiency, u, is assumed to be invariant across students in the same school. Second, all heterogeneity across observations is counted as 
inefficiency. In other words, excluding the inefficiency term in equation (1) there is no other source of individual heterogeneity. The former is not problematic in the present context; it would make little sense for a school to have differing efficiency levels across its students. However, the latter drawback is somewhat problematic in this instance, because of the limited number of variables that vary within a school.

\subsection{Determinants of Efficiency}

The second-stage estimation of the determinants of efficiency uses a standard ordinary least squares approach. The technical efficiency estimated in the first stage is now regressed on different institutional arrangements to find their association, if any, with efficiency. The estimated equation for school-level efficiency is

$\hat{t e_{s k}}=\lambda+z_{s k}^{-} \theta+\pi_{s k}$

where $\hat{t e}_{s k}$ is the technical efficiency measure from the first stage at the school-level, $z_{s k}^{-}$is a vector of institutional arrangements at the school-level, $\theta$ is the parameter of interest, as it represents the slope estimates on the institutional arrangements, and $\pi_{\mathrm{sk}}$ represents measurement error due to the need to estimate technical efficiency.

Although the efficiency estimates are regressed on an extensive set of institutional arrangements, it is possible that there are other unobservables that affect efficiency. Due to a lack of sufficient instrumental variables, this problem is unavoidable in the present context. As a result, these findings may only be identifying correlations and not causal relationships; nonetheless, the results are important for comparison to Woessman [15].

\subsection{Ordinary Least Squares}

Finally, we also estimate a standard educational production function using an ordinary least squares model (OLS) with the institutional arrangements included as regressors. This model can be written as:

$\mathrm{y}_{\text {isk }}=\alpha+\mathrm{x}_{\text {isk }} \beta+\mathrm{z}_{\mathrm{sk}} \theta+\varepsilon_{\text {isk }}$

where $y_{\text {isk }}$ is a measure of student achievement for student $i$ in school $\mathrm{s}$ in country $\mathrm{k}, \mathrm{x}_{\text {isk }}$ is a vector of inputs, $\mathrm{z}_{\mathrm{sk}}$ is a vector of institutional arrangements in school s in country $\mathrm{k}$, and $\varepsilon_{\text {isk }}$ represents purely idiosyncratic shocks which are uncorrelated with the choice of inputs.

\section{DATA}

The data are obtained from the 1999 Trends in International Mathematics and Science Study (TIMSS) ${ }^{1}$. TIMSS 1999 contains student, teacher and school background information across 38 different countries. The database includes responses of students, teachers and school principals on background questionnaires, as well as student achievement scores on internationally comparable math and science exams. The TIMSS 1999 dataset targeted "students

${ }^{1}$ The TIMSS 2003 dataset has been released as well; however, it does not include all of the institutional variables used herein. enrolled in the upper of the two adjacent grades that contain the largest proportion of 13-year olds at the time of testing" [18]. The student background questionnaires contain information on family background (such as parents' levels of education, and household composition), student demographics, and classroom activities. The teacher background questionnaire provides information on the teacher (such as age, gender, experience and education), the class (such as its size), the teacher's responsibilities (such as purchasing supplies and hiring teachers), and the availability of materials. The principal background questionnaire includes information on the school's characteristics, its degree of centralization in decision-making, and its distribution of responsibilities for a number of tasks.

Many of the questionnaire responses were transformed into categorical variables for the analysis. Further, the original database includes a number of students, teachers and principals that are missing responses, either because they failed to answer the questions, or because they were not administered the questions. This missing data would severely diminish the size of the data set, so the procedure detailed in Woessman [15] is followed to impute missing variables in the TIMSS 1999 data. Finally, we incorporate additional information from the World Education Indicators (WEI) 1999 a dataset collected jointly by the Organization for Economic Cooperation and Development (OECD) and the UNESCO Institute for Statistics (UIS) on per capita gross domestic product (GDP) and educational expenditures per student in each country. ${ }^{2}$ Data on GDP per capita and educational expenditures per student were not available for every country, so we are left with 28 countries and a total pool of over 120,000 individual students. From this full sample, we also estimate comparisons with sub-samples of countries that (i) are members of the Organization for Economic Cooperation and Development (OECD) and (ii) have curriculum-based external exit exams (CBEEEs).

Our measures of student achievement come from the mathematics and science scores of students who were administered proficiency tests as a part of the TIMSS survey. The tests were a combination of multiple choice and open response questions, where a considerable degree of care was placed on making the tests internationally comparable across languages and cultures. ${ }^{3}$

An extensive set of individual, class, and teacher characteristics available from the TIMSS data are used to obtain the technical efficiency measures. Specifically, the vector $x$ in (1) includes the following (in addition to a constant term):

Individual: age, a gender dummy, and a dummy for whether the student was born in the country of current residence;

\footnotetext{
${ }^{2}$ Some countries did not have GDP per capita and expenditure per student data available in the given year (1999), so it was supplemented, if available, by the previous year (1998).

${ }^{3}$ To limit the demands placed on test takers, each student was given only a subset of the full test. Item response theory methods were then utilized to insure the comparability of students taking different subsets [27].
} 
Family: two dummies for the highest level of education of the student's parents (at least a secondary education and at least a university education, versus not having a secondary education), a dummy for whether both parents were born in the country, four dummies for the number of books in the student's home (1-10 books, 11-25 books, 26-100 books, and 101-200 books, versus having more than 200 books), and a dummy for whether the student resides with both parents;

\section{Class: class size;}

Teacher: age, a gender dummy, years of teaching experience, three dummies indicating the highest level of education (a secondary degree, a bachelor's degree, and a master's degree or higher, versus not having a secondary degree);

Additionally, institutional characteristics from the TIMSS data and country specific variables from WEI are used in the second-stage analysis. Specifically, the vector

$\bar{z}$ in equation (4) includes the following:

Country Specifics: GDP per capita, and the level of education expenditures per student.

Influences on Curriculum: dummies indicating how much influence the following items have on the curriculum: external exams, individual teachers, subject teachers as a group, all teachers collectively, and teachers' unions;

Distribution of Responsibility: dummies indicating whether teachers, school administrators, or individuals outside of the school are responsible for the following duties: hiring teachers, deciding the school budget, purchasing supplies, and determining teacher salaries.

Teacher Influence: dummies indicating whether or not the teacher exerts a large influence on the following: the amount of money to be spent on supplies, what supplies are purchased, the subject matter taught, and the textbook chosen for the class.

\section{RESULTS}

We estimate both Cobb-Douglas and translog production functions. The F-test of the joint significance of the interaction terms in the translog model rejects the restrictions imposed in the Cobb-Douglas form at the $\mathrm{p}<0.05$ confidence level. Despite this, the results are similar to those in the translog models and are not discussed here for the sake of brevity, but are available from the author upon request. The first-stage translog production function estimates are shown in Table 1. The table includes four estimates; one each for math and science scores using the OLS model of equation (5) and one each for math and science scores using the fixed effects model shown in equation (1). There are 170 interaction terms used in the translog model, but these are suppressed in the tables. They are available from the author upon request. The first-stage results are not the main focus of this paper; however, it is important to note that the only variable that is significant in the fixed effects model for both math and science is the student's age. This is obviously specific to the student, and thus outside the control of school administrators. This finding is consistent which Hanushek's review of the education literature, which concludes that observable school inputs do not matter.

The focus of this paper is to compare the results of allowing institutional arrangements to impact educational achievement directly with the results of forcing the institutional arrangements to impact education achievement indirectly through a relationship with school-level efficiency. Thus, although the OLS model includes all the inputs of the fixed effects model, plus the institutional arrangements, we break up the results of the OLS model into two tables. Table 1, as discussed above, includes the same inputs included in the fixed effects model. Table 2 includes the coefficient estimated on the institutional arrangements from the OLS model and the coefficient estimated on the institutional arrangements from the regression on school-level efficiency (equation (4)).

As you can see from Table 2, the sign of the coefficient estimates are the same across the two models for all of the institutional variables, except for teachers being held responsible for deciding the school budget in science. The level of statistical significance of the estimates does vary some across the two models; however, it is not clear which specification is more accurate.

\subsection{Baseline Results}

\subsubsection{Distribution of Responsibility}

The responsibility for certain actions is divided between the schools being held responsible, the teachers being held responsible, or someone outside of the school holding the responsibility. The models analyzed here include dummy variables indicating that schools are responsible or teachers are responsible. Consonant with the literature, it is hypothesized that decentralization of decision-making authority leads to gains in efficiency in educational production if schools and teachers can make more informed decisions due to community specific information $[19,20]$.

\section{$\underline{\text { Responsibility for Hiring Teachers }}$}

The school dummy has a positive coefficient for hiring teachers in both math and science and in both the direct OLS and indirect efficiency models. However, these coefficient estimates are statistically significant at the $1 \%$ level in both math and science fixed effects models, whereas they are statistically insignificant in both math and science OLS models. The coefficients on the dummy for teachers holding this responsibility are negative, but not statistically significant in any of the subject and model combinations. These results suggest that giving schools the responsibility for hiring teachers is associated with higher levels of efficiency, as compared with the responsibility lying with teachers or someone outside of the school. This result is similar to the finding in Woessman [15] that students in schools who are given the autonomy over hiring decisions score significantly higher on math and science tests. Vegas [21] finds that decentralization of decision-making authority has a positive impact on student achievement. This would coincide with schools and/or teachers having responsibility for hiring teachers (and the other responsibilities discussed in this paper) as opposed to someone outside of the school 
Table 1. Translog Fixed Effects and OLS Production Function Estimates at the School Level with the Full Sample

\begin{tabular}{|c|c|c|c|c|c|c|c|c|}
\hline \multirow{3}{*}{$\begin{array}{l}\text { Independent } \\
\text { Variable }\end{array}$} & \multicolumn{4}{|c|}{ Math } & \multicolumn{4}{|c|}{ Science } \\
\hline & \multicolumn{2}{|c|}{ OLS } & \multicolumn{2}{|c|}{ Fixed Effects } & \multicolumn{2}{|c|}{ OLS } & \multicolumn{2}{|c|}{ Fixed Effects } \\
\hline & Coeff & Std Error & Coeff & Std Error & Coeff & Std Error & Coeff & Std Error \\
\hline Student's Age & $22.139 \ddagger$ & 2.677 & $7.602 \ddagger$ & 0.903 & $20.671 \dagger$ & 2.585 & $5.843 \%$ & 0.979 \\
\hline Class Size & $-1.075 \ddagger$ & 0.251 & -0.249 & 0.177 & $-1.077 \dagger$ & 0.309 & -0.081 & 0.173 \\
\hline Teacher's Experience & -0.168 & 0.204 & 0.187 & 0.147 & -0.070 & 0.188 & -0.005 & 0.117 \\
\hline Student's Sex & $-0.443 \ddagger$ & 0.137 & 0.125 & 0.083 & $-0.257^{*}$ & 0.145 & $0.182 *$ & 0.102 \\
\hline Born in Country & $-0.624 \dagger$ & 0.273 & 0.213 & 0.179 & $-0.867 \ddagger$ & 0.313 & -0.204 & 0.225 \\
\hline Live with both Parents & $-1.012 \ddagger$ & 0.164 & 0.080 & 0.112 & $-0.819 \ddagger$ & 0.180 & -0.054 & 0.141 \\
\hline Both Parents born in Country & $-1.074 \dagger$ & 0.285 & $-0.293 *$ & 0.170 & $-0.817 \ddagger$ & 0.299 & -0.122 & 0.207 \\
\hline Parents' Education (University) & 0.288 & 0.362 & $0.510^{*}$ & 0.301 & -0.122 & 0.385 & -0.140 & 0.348 \\
\hline Parents' Education 2 (Secondary) & $-0.642 \ddagger$ & 0.190 & -0.178 & 0.122 & -0.254 & 0.189 & 0.208 & 0.148 \\
\hline Parents' Education 3 (Master's) & $0.073 \dagger$ & 0.030 & 0.012 & 0.019 & 0.051 & 0.032 & 0.006 & 0.023 \\
\hline Books in Home (1-10) & -0.264 & 0.196 & 0.137 & 0.141 & $-0.415^{*}$ & 0.235 & -0.099 & 0.195 \\
\hline Books in Home (11-25) & $-0.890 \$$ & 0.177 & $-0.325 \ddagger$ & 0.123 & $-0.593 \ddagger$ & 0.192 & -0.186 & 0.148 \\
\hline Books in Home (26-100) & -0.292 & 0.188 & -0.076 & 0.115 & -0.180 & 0.185 & -0.020 & 0.121 \\
\hline Books in Home (101-200) & -0.191 & 0.199 & -0.060 & 0.117 & -0.140 & 0.196 & -0.093 & 0.123 \\
\hline Teacher's Sex & 0.130 & 0.204 & $0.367 \dagger$ & 0.145 & -0.026 & 0.197 & 0.157 & 0.119 \\
\hline Teacher's Age 1 & $0.376 \dagger$ & 0.164 & -0.083 & 0.111 & $0.259 *$ & 0.147 & 0.063 & 0.092 \\
\hline Teacher's Age 2 & $0.357 \dagger$ & 0.162 & -0.071 & 0.113 & $0.241 *$ & 0.145 & 0.067 & 0.091 \\
\hline Teacher's Age 3 & $0.285^{*}$ & 0.163 & -0.079 & 0.115 & 0.221 & 0.145 & 0.074 & 0.091 \\
\hline Teacher's Age 4 & $0.307 *$ & 0.164 & -0.098 & 0.118 & 0.200 & 0.145 & 0.071 & 0.091 \\
\hline Teacher's Age 5 & $0.343 \dagger$ & 0.165 & -0.124 & 0.123 & 0.229 & 0.148 & 0.052 & 0.092 \\
\hline Teacher's Education (Bachelor's) & -0.324 & 0.614 & $0.851 \dagger$ & 0.380 & $-1.884 \dagger$ & 0.741 & 0.126 & 0.451 \\
\hline Teacher's Education (Master's) & 0.192 & 0.236 & 0.091 & 0.139 & 0.087 & 0.246 & -0.137 & 0.146 \\
\hline
\end{tabular}

Note: Robust standard errors are clustered at the school level. $\$$ means significant at the $1 \%$ level; $\dagger$ means significant at the $5 \%$ level; * means significant at the $10 \%$ level. OLS regression also includes all institutional arrangements and per capita GDP and expenditure per student.

holding the responsibility. The coefficient on the school dummy for hiring teachers in the fixed effects models ranges in size from 0.0121 to 0.0174 , meaning that schools that have autonomy in hiring teachers are 1.21 to 1.74 percent more efficient than schools without this autonomy.

\section{Responsibility for Deciding School Budget}

The school dummy for deciding the school budget has positive coefficients in math and science in both models; however, they are only statistically significant in the OLS models. The teacher dummy for deciding the school budget has positive coefficients in math and science using OLS and in math using the fixed effects model, but the coefficient in science using the fixed effect model is negative. Only the result in math using OLS is statistically significant (at the $5 \%$ level).

The results in Woessman [15] are consistent with the hypothesis formed in Bishop and Woessman [19] and Fuchs and Woessman [20], that decentralization in decisionmaking increases educational efficiency; although, the findings presented here suggest that decentralization to the teacher level may have limited benefits in science.

\section{$\underline{\text { Responsibility for Purchasing Supplies }}$}

The coefficients on the school and teacher dummies for purchasing supplies are positive and statistically significant in both subjects using both models. Additionally, the sizes of the coefficients on the teacher dummies are also larger than those on the school dummies. This result shows that schools in which teachers have autonomy in purchasing supplies are 4.76 to 7.09 percent more efficient than schools without this autonomy.

\section{$\underline{\text { Responsibility for Teacher Salaries }}$}

The coefficients on the school dummy for deciding teacher salaries have positive signs in all four of the specifications, with three of them having statistical significance (all but the coefficient estimate in science using OLS). The coefficients on the teacher dummy are negative in both subjects using both models. This suggests that schools holding the responsibility over determining teacher salaries are more efficient than schools in which this responsibility is held by persons outside of the school, or by teachers themselves. This finding is similar to the result in Woessman [15] that students in schools with autonomy over 
Table 2. The Determinants of Efficiency at the School Level (Translog Model) Using OLS and Fixed Effects with the Full Sample

\begin{tabular}{|c|c|c|c|c|c|c|c|c|}
\hline \multirow{3}{*}{$\begin{array}{l}\text { Independent } \\
\text { Variable }\end{array}$} & \multicolumn{4}{|c|}{ Math } & \multicolumn{4}{|c|}{ Science } \\
\hline & \multicolumn{2}{|c|}{ OLS } & \multicolumn{2}{|c|}{ Fixed Effects } & \multicolumn{2}{|c|}{ OLS } & \multicolumn{2}{|c|}{ Fixed Effects } \\
\hline & Coeff & Std Error & Coeff & Std Error & Coeff & Std Error & Coeff & Std Error \\
\hline \multirow{2}{*}{\multicolumn{9}{|c|}{$\begin{array}{l}\text { Responsible for: } \\
\text { Hiring Teachers }\end{array}$}} \\
\hline & & & & & & & & \\
\hline Schools & 0.001 & 0.007 & $0.012 \ddagger$ & 0.004 & 0.001 & 0.007 & $0.017 \ddagger$ & 0.004 \\
\hline Teachers & -0.053 & 0.040 & -0.023 & 0.031 & -0.047 & 0.059 & -0.027 & 0.051 \\
\hline \multicolumn{9}{|l|}{ Deciding School Budget } \\
\hline Schools & $0.022 \dagger$ & 0.009 & $3.19 \mathrm{E}-04$ & 0.005 & $0.026 \%$ & 0.009 & 0.001 & 0.006 \\
\hline Teachers & $0.049 \dagger$ & 0.025 & 0.005 & 0.019 & 0.017 & 0.022 & -0.022 & 0.019 \\
\hline \multicolumn{9}{|l|}{ Purchasing Supplies } \\
\hline Schools & $0.051 \%$ & 0.013 & $0.042 \ddagger$ & 0.009 & $0.062 \hbar$ & 0.016 & $0.054 \dagger$ & 0.010 \\
\hline Teachers & $0.062 \ddagger$ & 0.014 & $0.048 \ddagger$ & 0.010 & 0.083 & 0.017 & $0.071 \dagger$ & 0.011 \\
\hline \multicolumn{9}{|l|}{ Determining Teacher's Salaries } \\
\hline Schools & $0.009^{*}$ & 0.005 & $0.012 \ddagger$ & 0.003 & 0.006 & 0.005 & $0.014 \ddagger$ & 0.004 \\
\hline Teachers & -0.014 & 0.032 & -0.016 & 0.023 & -0.013 & 0.029 & -0.010 & 0.025 \\
\hline \multicolumn{9}{|l|}{ Influences Curriculum } \\
\hline External Exams & $-0.012 *$ & 0.006 & $-0.009 \dagger$ & 0.004 & -0.001 & 0.006 & -0.006 & 0.004 \\
\hline Teachers Individually & $0.012 \dagger$ & 0.006 & $0.007 *$ & 0.004 & $0.011 \dagger$ & 0.005 & 0.003 & 0.004 \\
\hline Subject Teachers & $0.017 \ddagger$ & 0.006 & $0.012 \ddagger$ & 0.004 & $0.021 \ddagger$ & 0.006 & $0.020 \dagger$ & 0.004 \\
\hline Teachers Collectively & -0.009 & 0.006 & -0.006 & 0.004 & -0.009 & 0.005 & -0.004 & 0.004 \\
\hline Teachers' Unions & $-0.056 \dagger$ & 0.028 & $-0.046 \dagger$ & 0.020 & $-0.082 \ddagger$ & 0.031 & $-0.073 \ddagger$ & 0.023 \\
\hline \multicolumn{9}{|c|}{ Teachers have a large Influence on: } \\
\hline Money for Supplies & -0.015 & 0.012 & $-0.021 \dagger$ & 0.008 & -0.009 & 0.010 & $-0.014 *$ & 0.008 \\
\hline Kind of Supplies & $0.028 \ddagger$ & 0.007 & $0.019 \ddagger$ & 0.005 & $0.014 \dagger$ & 0.006 & $0.018 \ddagger$ & 0.005 \\
\hline Subject Matter & $-0.019 \ddagger$ & 0.005 & -0.015 & 0.004 & -0.014 & 0.005 & $-0.015 \ddagger$ & 0.004 \\
\hline Textbook & 0.004 & 0.006 & 0.006 & 0.004 & 0.000 & 0.005 & 0.005 & 0.005 \\
\hline GDP per capita & $-3.18 \mathrm{E}-06 \%$ & 7.30E-07 & $-8.99 \mathrm{E}-07 \ddagger$ & 4.60E-07 & $3.74 \mathrm{E}-07$ & 8.09E-07 & $-1.01 \mathrm{E}-07$ & $5.22 \mathrm{E}-07$ \\
\hline Expenditure per student & $2.52 \mathrm{E}-05 t$ & $2.54 \mathrm{E}-06$ & $9.70 \mathrm{E}-05 \ddagger$ & $1.59 \mathrm{E}-06$ & $7.93 \mathrm{E}-06 \%$ & $2.73 \mathrm{E}-06$ & $7.09 \mathrm{E}-06 \ddagger$ & $1.72 \mathrm{E}-06$ \\
\hline
\end{tabular}

Note: Robust standard errors are clustered at the school level. $\$$ means significant at the $1 \%$ level; $\uparrow$ means significant at the $5 \%$ level; $*$ means significant at the $10 \%$ level. OLS regressions also included the background variables in Table $\mathbf{1 .}$

teacher salaries score higher on math and science test scores. Additionally, this is also consistent with the hypothesis formed in Bishop and Woessman [19] and Fuchs and Woessman [20], that decentralization in decision-making increases educational efficiency. Although, in this instance it appears that decentralization to the school level is beneficial, decentralization to the teacher level may be detrimental. The positive and significant coefficients on the school dummy for determining teacher salaries means that schools that have autonomy in hiring teachers are 1.16 to 1.42 percent more efficient than schools without this autonomy.

Policy Implications: someone within the schools should hold the responsibility for purchasing supplies.

\subsubsection{Influences on Curriculum}

The following variables are known to either have a large effect on curriculum or to have no effect on the curriculum. The models analyzed here include a dummy variable indicating that the variable in question has a large influence on the curriculum.

\section{External Exams}

The coefficient on external exams is negative in all four of the specifications, but these estimates are only statistically significant in math. This suggests that allowing external exams to influence a school's curriculum is negatively associated with efficiency. It has been previously 
hypothesized that external exams provide an incentive for teachers to work harder and thus lead to higher student achievement; this hypothesis was shown to be true in Bishop [22]. Additionally, Woessman [23] finds that students in countries with central exit exams score significantly higher on international achievement tests than students in countries without central exit exams. However, it may be that external exams force teachers to "teach to the test," limiting the amount of time spent on other important areas (which may have been covered on the TIMSS exam), leading to the negative relationship found here and in Woessman [15]. The negative and significant coefficients on the dummy for external exams in math using the fixed effect model tells us that schools with influential external exams are 0.929 percent less efficient than schools without influential external exams.

\section{Teachers Individually}

The dummy variable indicating that teachers individually have a large influence on curriculum has a positive coefficient in all four models; however, it is not statistically significant in science using the fixed effects model. The suggestion here is that allowing teachers to have an individual influence on the curriculum is associated with higher levels of efficiency. Similarly, Woessman [15] found that students in schools where teachers individually had a large influence on curriculum score higher in math and science tests. Vegas [21] also found student achievement to be positively influenced by greater teacher autonomy, but only when the decision-making authority is decentralized. The fixed effects result in math means that schools where teachers individually have a large influence on curriculum are 0.707 percent more efficient than schools where teachers individually have no influence over curriculum.

\section{Subject Teachers}

The coefficients on subject teachers are positive and statistically significant in both subjects using both models. This is contrary to Woessman's [15] finding of a significant negative relationship between subject teachers influencing curriculum and student achievement. This change from Woessman [15] could be due to the fact that we do not have all of the same variables (e.g. private school enrollment) or it could simply be a result of using two different years of data.

\section{Teachers Collectively}

The coefficients on the dummy for teachers collectively are negative, but statistically insignificant in both subjects using both models. These coefficients are of the sign as those found in Woessman [15], but his were also found to be statistically significant.

\section{Teachers' Unions}

The coefficient on teachers' unions is negative and statistically significant in all four models. This finding is analogous to the finding in Woessman [15] that allowing teachers' unions to have a large influence on curriculum is damaging to student achievement. Similarly, Hoxby [24] finds that teachers' unions increase the level of educational inputs, but decrease productivity so much that the net effect on student achievement is negative. The fixed effect results mean that schools where teachers' unions have a large influence on curriculum are 4.6 to 7.28 percent less efficient than schools where teachers' unions have no influence over curriculum. The coefficient estimate in science is larger than the estimates of any of the other institutional arrangements and the estimate in math is surpassed in magnitude by only the coefficient on teachers holding the responsibility for purchasing supplies. Thus, teachers' unions have a very strong relationship with school efficiency, relative to the other institutional factors.

Policy Implications: subject teachers (as a collective) should hold a strong influence over the curriculum, while teachers' unions should not have a strong influence over the curriculum.

\subsubsection{Teacher Influence}

Teachers are known to either have a large influence or no influence on the following choices. The models analyzed here include a dummy variable indicating that teachers have a large influence on the choice in question.

\section{Money for Supplies}

The coefficients on the dummy variable indicating that class teachers have a large influence on money for supplies are negative in both subjects and both models, but the coefficients are statistically significant only using the fixed effects model. This is in contrast to the positive and statistically significant effect of teachers influencing money for supplies on tests in science found in Woessman [15].

\section{Kind of Supplies}

The dummy variable for teachers holding a large influence on the kind of supplies has positive and statistically significant coefficients in both subjects using both models. These results suggest a positive relationship between teachers influencing the kind of supplies and the efficiency of the school, which is consistent with the benefits to decentralization found in Vegas [21]. The findings in Woessman [15] show a positive relationship between teachers influencing the kind of supplies and student test scores, but only in science. Our results suggest that the relationship between teachers influencing the kind of supplies and school efficiency is positive across both subjects.

\section{Subject Matter}

The coefficient on subject matter is negative and statistically significant in both subjects using both models. Woessman [15] also found a negative coefficient on this variable for both math and science test scores, but his findings were statistically insignificant. However, these results are opposite of what was expected based on the positive relationship between decentralization and student achievement found in Vegas [21]. Although decentralization in general may lead to increased student outcomes, it appears that decentralizing the choice of subject matter to the teacher level is negatively associated with educational efficiency. 


\section{$\underline{\text { Textbook }}$}

The coefficient estimates on the dummy for teachers having a large influence on the choice of textbook are statistically insignificant in both subjects using both models. These estimates are positive in all but the OLS model in science. Thus, the relationship between teachers influencing textbook choice and school efficiency is unclear.

Policy Implications: teachers should have a strong influence over the kind of supplies used in the classroom, but they should not have a strong influence over the subject matter taught.

\subsubsection{Country Specifics}

The following are country-level variables thought to impact efficiency in education. Some might question why these variables are not placed in the first-stage production function; however, because these are country-level variables, they would be dropped from the school-level fixed effects equation we use.

\section{GDP Per Capita}

The country's GDP per capita has negative and statistically significant coefficients using both models in math. In science, this coefficient estimate is positive using OLS, but negative using fixed effects; neither of these estimates are statistically significant. The result in math is opposite of the positive and statistically significant relationship between GDP per capita and test scores found in Woessman [15]. It could be that students in countries with higher standards of living (as measured by GDP per capita) have less of an incentive to do well in school. This is likely just an association, not a causal finding.

\section{Expenditures Per Student}

The variable measuring the level of expenditures per student in a country has positive and statistically significant coefficients in both subjects using both models. This is similar to the finding in Millimet and Collier [25] of robust efficiency spillovers across school districts in the same county, only when the district operates in a financially flexible environment

\subsection{Sensitivity Analysis}

To assess the sensitivity of our baseline results, we reconducted our analysis using two different sub-samples of the data:

OECD Only: using only students from member countries of the OECD; and

(ii) CBEEE Only: using only students from countries that have curriculum-based external exit exams (CBEEEs).

The results of the analysis using only students from member countries of the OECD are displayed in Tables 3 and 4. The results of the analysis using only students from countries that have curriculum-based external exit exams (CBEEEs) are displayed in Tables 5 and $\mathbf{6}$.

\subsubsection{Distribution of Responsibility}

\section{Responsibility for Hiring Teachers}

The sub-sample results show drastic changes in the coefficient estimates on the dummies for schools and teachers holding the responsibility for hiring teachers. When we limit the sample to countries within the OECD, the OLS estimates in both math and science on the dummy for schools being responsible for hiring teachers switch signs from the full sample results to negative coefficient estimates; only the math result is statistically significant. The fixed effect estimate in math on the dummy for schools being responsible for hiring teachers is virtually indifferent between the full sample and OECD sub-sample, but the science estimate in the OECD sub-sample becomes negative (but statistically insignificant), whereas it was positive in the full sample.

The OLS and fixed effects coefficient estimates in science on the dummy for teachers being responsible for hiring teachers remain negative (as they were in the full sample) in the OECD sub-sample, but also become statistically significant. In math, this OLS estimate also becomes statistically significant, but the fixed effect estimate remains positive and statistically insignificant.

The coefficient estimates on the dummies for both schools and teachers holding the responsibility for hiring teachers are negative across both subjects and both models in the CBEEE sub-sample, with the coefficient estimates on the dummy for teacher responsibility holding statistical significance. These changes in the coefficient estimates between the full sample and the CBEEE sub-sample are similar to the findings in Woessman [26] and Fuchs and Woessman [20] that there is strong heterogeneity for the effects of school autonomy.

\section{$\underline{\text { Responsibility for Deciding School Budget }}$}

The coefficient estimates on the school dummy for deciding school budget remains positive for the fixed effects model in math and science across both sub-samples; and gains statistical significance in the CBEEE sub-sample. These estimates remain positive across all sub-samples in both subjects for the OLS model except for the OECD subsample in math, which results in a negative, but statistically insignificant coefficient estimate.

The coefficient estimates on the teacher dummy for deciding school budget become larger and more positive in both models with the CBEEE sub-sample for math and science. On the contrary, these estimates become smaller or more negative for the OECD sub-sample across both subjects and models.

These results suggest that the relationships between decentralized responsibility for deciding school budgets (either at the school or teacher level) and both school efficiency and student achievement are of a greater magnitude for schools with CBEEEs. 
Table 3. Translog Fixed Effects and OLS Production Function Estimates at the School Level with the Only Countries in the OECD

\begin{tabular}{|c|c|c|c|c|c|c|c|c|}
\hline \multirow{3}{*}{$\begin{array}{l}\text { Independent } \\
\text { Variable }\end{array}$} & \multicolumn{4}{|c|}{ Math } & \multicolumn{4}{|c|}{ Science } \\
\hline & \multicolumn{2}{|c|}{ OLS } & \multicolumn{2}{|c|}{ Fixed Effects } & \multicolumn{2}{|c|}{ OLS } & \multicolumn{2}{|c|}{ Fixed Effects } \\
\hline & Coeff & Std Error & Coeff & Std Error & Coeff & Std Error & Coeff & Std Error \\
\hline Student's Age & $6.711 \%$ & 1.797 & $6.744 \$$ & 1.074 & $6.239 \ddagger$ & 1.665 & $5.130 \ddagger$ & 1.241 \\
\hline Class Size & $-1.675 \dagger$ & 0.306 & 0.053 & 0.272 & $-1.117 \ddagger$ & 0.320 & $-0.529 *$ & 0.274 \\
\hline Teacher's Experience & -0.230 & 0.189 & $8.449 \$$ & 4.210 & -0.241 & 0.164 & -0.151 & 0.136 \\
\hline Student's Sex & $-0.230 *$ & 0.123 & 0.069 & 0.093 & $-0.255 \dagger$ & 0.122 & -0.029 & 0.103 \\
\hline Born in Country & 0.316 & 0.255 & $0.552 \ddagger$ & 0.209 & 0.157 & 0.255 & 0.269 & 0.220 \\
\hline Live with both Parents & $-0.930 \ddagger$ & 0.192 & 0.127 & 0.151 & $-0.990+$ & 0.217 & $-0.308^{*}$ & 0.177 \\
\hline Both Parents born in Country & $-0.522 \dagger$ & 0.261 & $-0.332 *$ & 0.194 & -0.322 & 0.268 & -0.191 & 0.220 \\
\hline Parents' Education (University) & 0.537 & 0.547 & $0.841 \dagger$ & 0.425 & 0.334 & 0.700 & 0.752 & 0.633 \\
\hline Parents' Education 2 (Secondary) & 0.048 & 0.203 & $-0.341 \dagger$ & 0.151 & -0.105 & 0.202 & -0.124 & 0.175 \\
\hline Parents' Education 3 (Master's) & $0.123 \$$ & 0.046 & 0.025 & 0.026 & $0.120 \%$ & 0.032 & 0.056 & 0.028 \\
\hline Books in Home (1-10) & 0.267 & 0.241 & 0.086 & 0.201 & 0.094 & 0.255 & 0.009 & 0.232 \\
\hline Books in Home (11-25) & $-0.483 \ddagger$ & 0.182 & $-0.315 \dagger$ & 0.149 & -0.187 & 0.200 & -0.112 & 0.171 \\
\hline Books in Home (26-100) & -0.226 & 0.164 & -0.098 & 0.127 & -0.122 & 0.164 & -0.014 & 0.136 \\
\hline Books in Home (101-200) & -0.130 & 0.167 & 0.042 & 0.124 & -0.022 & 0.169 & 0.041 & 0.142 \\
\hline Teacher's Sex & $0.445 \dagger$ & 0.179 & $20.210 \dagger$ & 10.037 & -0.015 & 0.165 & 0.155 & 0.146 \\
\hline Teacher's Age 1 & $0.246^{*}$ & 0.142 & $-9.858 \dagger$ & 5.012 & 0.217 & 0.138 & $0.209 *$ & 0.113 \\
\hline Teacher's Age 2 & 0.217 & 0.142 & $-9.846 \dagger$ & 5.011 & 0.213 & 0.137 & $0.208^{*}$ & 0.113 \\
\hline Teacher's Age 3 & 0.190 & 0.142 & $-9.850 \dagger$ & 5.011 & 0.218 & 0.136 & $0.215^{*}$ & 0.112 \\
\hline Teacher's Age 4 & 0.197 & 0.142 & $-9.854 \dagger$ & 5.012 & 0.198 & 0.135 & $0.208^{*}$ & 0.112 \\
\hline Teacher's Age 5 & 0.202 & 0.143 & $-9.889 \dagger$ & 5.012 & 0.215 & 0.136 & 0.181 & 0.113 \\
\hline Teacher's Education (Bachelor's) & -0.521 & 0.905 & - & - & 0.721 & 1.022 & $1.473 \dagger$ & 0.741 \\
\hline Teacher's Education (Master's) & $0.795 \ddagger$ & 0.198 & $0.309 *$ & 0.160 & $0.564 \ddagger$ & 0.192 & 0.028 & 0.162 \\
\hline
\end{tabular}

Note: Robust standard errors are clustered at the school level. $\$$ means significant at the $1 \%$ level; $\dagger$ means significant at the $5 \%$ level; $*$ means significant at the $10 \%$ level. OLS regression also includes all institutional arrangements and per capita GDP and expenditure per student.

\section{Responsibility for Purchasing Supplies}

The coefficients on the school and teacher dummies for purchasing supplies in math become insignificant in both sub-samples using both models. Alternatively, the school dummies for purchasing supplies in science are negative and significant in the OECD sub-sample using both OLS and fixed effects models. The coefficients on the teacher dummies in science with the OECD sub-sample are also negative for both models, but do not have statistical significance. The coefficients on the teacher dummies in science with the CBEEE sub-sample remain positive and statistically significant in both models, as they were in the full sample.

This suggests that the optimal level of responsibility for purchasing supplies is highly dependent on other factors, including the subject and the presence of CBEEEs. There also appears to be some unknown factors present in OECD countries that are not present in the other countries included in the full sample that impact the relationship between the responsibility for purchasing supplies and both student achievement and school efficiency.

\section{Responsibility for Teacher Salaries}

There are two changes in the coefficients on the school and teacher dummies for deciding teacher salaries using the sub-samples. First, the CBEEE sub-sample estimate in math on the teacher dummy is positive and statistically significant in both models, whereas these coefficients were negative and statistically insignificant using the full sample. Second, the OECD sub-sample estimate in science on the teacher dummy is negative and statistically significant in both models, whereas these coefficients were negative and statistically insignificant using the full sample. Again, there appears to be unknown factors present in OECD countries that are not present in the other countries in the full sample that are impacting our results. Additionally, the presence of CBEEEs seems to alter the relationships between institutional arrangements and student achievement and school efficiency. This is further evidence of the finding in Woessman [26] of strong heterogeneity for the effects of school autonomy.

Policy Implications: teachers in OECD countries should not be responsible for hiring science teachers or for 
Table 4. Translog Fixed Effects and OLS Production Function Estimates at the School Level with the Only Countries that have CBEEEs

\begin{tabular}{|c|c|c|c|c|c|c|c|c|}
\hline \multirow{3}{*}{$\begin{array}{l}\text { Independent } \\
\text { Variable }\end{array}$} & \multicolumn{4}{|c|}{ Math } & \multicolumn{4}{|c|}{ Science } \\
\hline & \multicolumn{2}{|c|}{ OLS } & \multicolumn{2}{|c|}{ Fixed Effects } & \multicolumn{2}{|c|}{ OLS } & \multicolumn{2}{|c|}{ Fixed Effects } \\
\hline & Coeff & Std Error & Coeff & Std Error & Coeff & Std Error & Coeff & Std Error \\
\hline Student's Age & $8.606 \%$ & 1.767 & $5.761 \ddagger$ & 1.062 & $7.326 \ddagger$ & 1.840 & $4.867 \ddagger$ & 1.230 \\
\hline Class Size & $-1.475 \ddagger$ & 0.325 & $-0.601+$ & 0.208 & $-1.221 \dagger$ & 0.365 & -0.391 & 0.283 \\
\hline Teacher's Experience & -0.322 & 0.226 & 0.117 & 0.145 & $-0.503 \ddagger$ & 0.182 & -0.132 & 0.132 \\
\hline Born in Country & 0.242 & 0.315 & 0.328 & 0.204 & 0.314 & 0.262 & 0.210 & 0.222 \\
\hline Live with both Parents & $-0.847 \ddagger$ & 0.206 & -0.157 & 0.158 & $-0.966 \ddagger$ & 0.240 & $-0.414 \dagger$ & 0.186 \\
\hline Both Parents born in Country & $-0.940 \ddagger$ & 0.292 & $-0.514 \ddagger$ & 0.194 & $-0.895 \ddagger$ & 0.275 & -0.296 & 0.220 \\
\hline Parents' Education (University) & 0.502 & 0.647 & 0.430 & 0.530 & 1.399 & 0.860 & 0.632 & 0.654 \\
\hline Books in Home (11-25) & -0.278 & 0.225 & $-0.358 \dagger$ & 0.175 & 0.047 & 0.230 & 0.011 & 0.191 \\
\hline Books in Home (26-100) & -0.157 & 0.174 & -0.031 & 0.128 & 0.107 & 0.182 & -0.002 & 0.141 \\
\hline Books in Home (101-200) & -0.165 & 0.165 & 0.158 & 0.123 & -0.045 & 0.175 & 0.130 & 0.139 \\
\hline Teacher's Sex & $0.590 \%$ & 0.228 & $0.469 \ddagger$ & 0.155 & 0.162 & 0.207 & $0.353 \dagger$ & 0.151 \\
\hline Teacher's Age 1 & $0.436 \dagger$ & 0.180 & -0.038 & 0.116 & $0.585 \ddagger$ & 0.161 & 0.165 & 0.111 \\
\hline Teacher's Age 2 & $0.410 \dagger$ & 0.181 & -0.021 & 0.117 & $0.566 \ddagger$ & 0.158 & 0.165 & 0.110 \\
\hline Teacher's Age 3 & $0.376 \dagger$ & 0.181 & -0.020 & 0.120 & $0.567 \ddagger$ & 0.158 & 0.174 & 0.109 \\
\hline Teacher's Age 4 & $0.383 \dagger$ & 0.181 & -0.044 & 0.125 & $0.549 \ddagger$ & 0.157 & 0.173 & 0.109 \\
\hline
\end{tabular}

Note: Robust standard errors are clustered at the school level. $\$$ means significant at the $1 \%$ level; $\dagger$ means significant at the $5 \%$ level; * means significant at the $10 \%$ level. OLS regression also includes all institutional arrangements and per capita GDP and expenditure per student.

determining science teacher salaries. Similarly, teachers should not be responsible for hiring science or math teachers when CBEEs are present. School administrators should be responsible for deciding school budgets and determining teachers' salaries when CBEEs are present. However, the responsibility for purchasing science supplies should not be held by school administrators in OECD countries.

\subsubsection{Influences on Curriculum}

\section{External Exams}

The coefficients on external exams remain negative across both models and both sub-samples in math, but the only statistically significant estimate in the sub-samples using math scores occurs with the OLS model in the OECD sub-sample. The coefficient estimates on this variable in science are actually positive and statistically significant for the CBEEE sub-sample across both models; while these estimates are statistically insignificant for the OECD subsample across both models. This suggests that the relationship between external exams and student achievement and school efficiency are different for countries with and without curriculum based external exit exams and across subjects.

Teachers Individually

There are no changes in the signs of the coefficient estimates on the dummy variable for teachers individually influencing curriculum across the OECD and CBEEE subsamples. This suggests that allowing teachers greater control over the curriculum is beneficial to students in OECD and non-OECD countries and in countries with and without CBEEEs.

\section{$\underline{\text { Subject Teachers }}$}

There is only one change in the signs of the coefficient estimates on the dummy variable for subject teachers influencing curriculum across the OECD and CBEEE subsamples. The coefficient estimate on subject teachers in science using the fixed effects model with the OECD subsample is negative, but statistically insignificant. This tells us that the positive relationship found in the full sample is fairly robust to sample selection. 
Table 5. The Determinants of Efficiency at the School Level (Translog Model) using OLS and Fixed Effects in OECD Countries

\begin{tabular}{|c|c|c|c|c|c|c|c|c|}
\hline \multirow{3}{*}{$\begin{array}{l}\text { Independent } \\
\text { Variable }\end{array}$} & \multicolumn{4}{|c|}{ Math } & \multicolumn{4}{|c|}{ Science } \\
\hline & \multicolumn{2}{|c|}{ OLS } & \multicolumn{2}{|c|}{ Fixed Effects } & \multicolumn{2}{|c|}{ OLS } & \multicolumn{2}{|c|}{ Fixed Effects } \\
\hline & Coeff & Std Error & Coeff & Std Error & Coeff & Std Error & Coeff & Std Error \\
\hline \multirow{2}{*}{\multicolumn{9}{|c|}{$\begin{array}{l}\text { Responsible for: } \\
\text { Hiring Teachers }\end{array}$}} \\
\hline & & & & & & & & \\
\hline Schools & $-0.012 \dagger$ & 0.005 & 0.002 & 0.002 & -0.003 & 0.005 & -0.001 & 0.004 \\
\hline Teachers & $-0.104 \$$ & 0.014 & 0.001 & 0.002 & $-0.074 \dagger$ & 0.026 & $-0.050^{*}$ & 0.028 \\
\hline \multicolumn{9}{|l|}{ Deciding School Budget } \\
\hline Schools & -0.006 & 0.008 & 0.001 & 0.001 & 0.005 & 0.009 & 0.002 & 0.006 \\
\hline Teachers & 0.007 & 0.014 & $-3.72 \mathrm{E}-04$ & 0.001 & -0.016 & 0.017 & -0.006 & 0.014 \\
\hline \multicolumn{9}{|l|}{ Purchasing Supplies } \\
\hline Schools & -0.011 & 0.011 & $-1.65 \mathrm{E}-04$ & 4.46E-04 & $-0.031 \dagger$ & 0.009 & $-0.023 \$$ & 0.008 \\
\hline Teachers & $-2.84 \mathrm{E}-04$ & 0.011 & $3.93 \mathrm{E}-05$ & $4.27 \mathrm{E}-04$ & -0.011 & 0.010 & -0.002 & 0.009 \\
\hline \multicolumn{9}{|l|}{ Determining Teacher's Salaries } \\
\hline Schools & $0.010 \dagger$ & 0.004 & -0.002 & 0.002 & 0.006 & 0.004 & $0.007 \dagger$ & 0.003 \\
\hline Teachers & -0.040 & 0.030 & -0.002 & 0.002 & $-0.054 \dagger$ & 0.023 & $-0.060 \$$ & 0.022 \\
\hline \multicolumn{9}{|l|}{ Influences Curriculum } \\
\hline External Exams & $-0.017 \ddagger$ & 0.005 & $1.14 \mathrm{E}-04$ & $1.60 \mathrm{E}-04$ & 0.003 & 0.005 & -0.001 & 0.004 \\
\hline Teachers Individually & $0.011 \dagger$ & 0.004 & 0.003 & 0.003 & $0.007 *$ & 0.004 & 0.005 & 0.003 \\
\hline Subject Teachers & $0.020 \ddagger$ & 0.005 & -0.001 & 0.001 & 0.024 & 0.005 & $0.021 \ddagger$ & 0.004 \\
\hline Teachers Collectively & $-0.011 \dagger$ & 0.005 & -0.001 & 0.001 & $-0.009 \dagger$ & 0.004 & $-0.012 \ddagger$ & 0.004 \\
\hline Teachers' Unions & -0.043 & 0.032 & -0.001 & 0.002 & $-0.070 \ddagger$ & 0.026 & $-0.064 \$$ & 0.021 \\
\hline \multicolumn{9}{|c|}{ Teachers have a large Influence on: } \\
\hline Money for Supplies & $-0.022 \dagger$ & 0.010 & -0.004 & 0.004 & -0.003 & 0.006 & 0.000 & 0.007 \\
\hline Kind of Supplies & $0.016 \ddagger$ & 0.005 & 0.004 & 0.004 & $0.010 \dagger$ & 0.004 & $0.009 \dagger$ & 0.004 \\
\hline Subject Matter & -0.001 & 0.005 & 0.002 & 0.002 & $-0.008 \dagger$ & 0.004 & -0.005 & 0.004 \\
\hline Textbook & $0.014 \ddagger$ & 0.005 & -0.002 & 0.002 & $0.015 \$$ & 0.004 & $0.013 \ddagger$ & 0.004 \\
\hline GDP per capita & $-8.12 \mathrm{E}-06+$ & $6.62 \mathrm{E}-07$ & $-6.91 \mathrm{E}-08$ & $6.98 \mathrm{E}-08$ & $-4.56 \mathrm{E}-06 \%$ & 7.01E-07 & $-9.01 \mathrm{E}-07 \dagger$ & $5.07 \mathrm{E}-07$ \\
\hline Expenditure per student & $2.81 \mathrm{E}-05 \ddagger$ & 2.33E-06 & $-1.04 \mathrm{E}-07$ & $1.16 \mathrm{E}-07$ & $1.33 \mathrm{E}-05 \$$ & $2.32 \mathrm{E}-06$ & $-1.41 \mathrm{E}-07$ & $1.66 \mathrm{E}-06$ \\
\hline
\end{tabular}

Note: Robust standard errors are clustered at the school level. $\$$ means significant at the $1 \%$ level; $\dagger$ means significant at the $5 \%$ level; * means significant at the $10 \%$ level. OLS regressions also included the background variables in Table $\mathbf{3}$.

\section{Teachers Collectively}

The coefficients on the dummy for teachers collectively remain negative across all estimates using the sub-samples. These coefficients actually gain statistical significance in the OECD sub-sample with both models in science and for the OLS model only in math. Only the fixed effects estimate in math holds statistical significance in the CBEEE sub-sample. It appears that the relationships between allowing teachers to collectively influence the curriculum and student achievement and school efficiency are of different magnitudes across different samples of countries.

\section{Teachers' Unions}

The coefficient estimates on teachers' unions remain negative across both sub-samples using both models in math and science. These estimates are also statistically significant in all but the OECD sub-sample estimates in math. Thus, teachers' unions not only have a very strong relationship with school efficiency, relative to the other institutional factors, but also maintain this strong relationship across different sub-samples of countries.

Policy Implications: neither teachers collectively nor teachers' unions should have a strong influence over science curriculum in OECD countries. Similarly, teachers' unions should not have a strong influence over math or science curriculum when CBEEs are present. Alternatively, individual teachers should have a strong influence over curriculum when CBEEs are present. Lastly, subject teachers and external exams should have a strong influence over science curriculum when CBEEs are present. 
Table 6. The Determinants of Efficiency at the School Level (Translog Model) Using OLS and Fixed Effects in Countries with CBEEEs

\begin{tabular}{|c|c|c|c|c|c|c|c|c|}
\hline \multirow{3}{*}{$\begin{array}{l}\text { Independent } \\
\text { Variable }\end{array}$} & \multicolumn{4}{|c|}{ Math } & \multicolumn{4}{|c|}{ Science } \\
\hline & \multicolumn{2}{|c|}{ OLS } & \multicolumn{2}{|c|}{ Fixed Effects } & \multicolumn{2}{|c|}{ OLS } & \multicolumn{2}{|c|}{ Fixed Effects } \\
\hline & Coeff & Std Error & Coeff & Std Error & Coeff & Std Error & Coeff & Std Error \\
\hline \multirow{2}{*}{\multicolumn{9}{|c|}{$\begin{array}{l}\text { Responsible for: } \\
\text { Hiring Teachers }\end{array}$}} \\
\hline & & & & & & & & \\
\hline Schools & -0.007 & 0.007 & $-0.010 \dagger$ & 0.004 & -0.001 & 0.007 & -0.005 & 0.005 \\
\hline Teachers & $-0.100 \ddagger$ & 0.011 & $-0.096 \$$ & 0.006 & -0.066 & 0.013 & $-0.082 \ddagger$ & 0.007 \\
\hline \multicolumn{9}{|l|}{ Deciding School Budget } \\
\hline Schools & $0.034 \dagger$ & 0.009 & $0.014 \dagger$ & 0.006 & $0.027 \dagger$ & 0.011 & $0.019 \ddagger$ & 0.007 \\
\hline Teachers & $0.065 \ddagger$ & 0.016 & $0.052 \hbar$ & 0.010 & 0.025 & 0.019 & $0.036 \ddagger$ & 0.014 \\
\hline \multicolumn{9}{|l|}{ Purchasing Supplies } \\
\hline Schools & 0.008 & 0.018 & 0.002 & 0.011 & 0.033 & 0.023 & 0.018 & 0.013 \\
\hline Teachers & 0.028 & 0.019 & 0.014 & 0.011 & $0.058 \dagger$ & 0.023 & $0.040 \ddagger$ & 0.014 \\
\hline \multicolumn{9}{|l|}{ Determining Teacher's Salaries } \\
\hline Schools & $0.018 \ddagger$ & 0.004 & $0.015 \$$ & 0.003 & $0.014 \$$ & 0.004 & $0.014 \ddagger$ & 0.003 \\
\hline Teachers & $0.040 \%$ & 0.015 & $0.030 \%$ & 0.010 & 0.016 & 0.014 & 0.012 & 0.011 \\
\hline \multicolumn{9}{|l|}{ Influences Curriculum } \\
\hline External Exams & -0.001 & 0.006 & -0.004 & 0.004 & 0.015 & 0.005 & $0.008 \dagger$ & 0.004 \\
\hline Teachers Individually & $0.024 \ddagger$ & 0.005 & $0.018 \$$ & 0.004 & $0.017 \$$ & 0.005 & $0.013 \ddagger$ & 0.004 \\
\hline Subject Teachers & 0.005 & 0.006 & 0.003 & 0.004 & $0.013 \dagger$ & 0.006 & $0.013 t$ & 0.004 \\
\hline Teachers Collectively & -0.004 & 0.006 & $-0.006^{*}$ & 0.004 & -0.006 & 0.005 & -0.006 & 0.004 \\
\hline Teachers' Unions & $-0.049 *$ & 0.026 & $-0.038 \dagger$ & 0.018 & $-0.075 \$$ & 0.023 & $-0.068 \ddagger$ & 0.019 \\
\hline \multicolumn{9}{|c|}{ Teachers have a large Influence on: } \\
\hline Money for Supplies & -0.006 & 0.011 & -0.004 & 0.008 & 0.007 & 0.007 & 0.011 & 0.008 \\
\hline Kind of Supplies & $0.015 \dagger$ & 0.007 & $0.009 \dagger$ & 0.005 & 0.006 & 0.005 & 0.004 & 0.005 \\
\hline Subject Matter & -0.006 & 0.005 & 0.001 & 0.004 & -0.004 & 0.004 & -0.003 & 0.004 \\
\hline Textbook & $-4.56 \mathrm{E}-04$ & 0.006 & -0.003 & 0.004 & 0.002 & 0.005 & 0.003 & 0.005 \\
\hline GDP per capita & $-1.00 \mathrm{E}-06$ & $1.01 \mathrm{E}-06$ & 7.02E-07 & $6.34 \mathrm{E}-07$ & $-1.37 \mathrm{E}-06$ & $1.04 \mathrm{E}-06$ & $5.71 \mathrm{E}-07$ & $7.76 \mathrm{E}-07$ \\
\hline Expenditure per student & $1.66 \mathrm{E}-06$ & $3.96 \mathrm{E}-06$ & $-3.23 \mathrm{E}-06$ & $2.45 \mathrm{E}-06$ & $1.03 \mathrm{E}-06$ & $3.90 \mathrm{E}-06$ & $-5.58 \mathrm{E}-06^{*}$ & $2.91 \mathrm{E}-06$ \\
\hline
\end{tabular}

Note: Robust standard errors are clustered at the school level. $\$$ means significant at the $1 \%$ level; $\dagger$ means significant at the $5 \%$ level; $*$ means significant at the $10 \%$ level. OLS regressions also included the background variables in Table 4

\subsubsection{Teacher Influence}

\section{Money for Supplies}

The coefficients on the dummy variable indicating that class teachers have a large influence on money for supplies remain negative for all of the sub-sample estimates in math. However, the CBEEE estimates in science are positive using both models and the OECD estimate in math using the fixed effects model in science in positive. Although these estimates do change signs from the full sample to the subsamples in science, none of these estimates are statistically significant. It appears that the effect of giving teachers a large influence over money for supplies is largely dependent on subject, whether or not the country has curriculum based external exit exams and other unobservable factors in OECD countries.

\section{Kind of Supplies}

The sub-sample coefficient estimates on the dummy variable for teachers holding a large influence on the kind of supplies are largely unchanged from their full sample counterparts. All of these estimates remain positive, however, the CBEEE estimates in science are statistically insignificant. This suggests that our full sample finding is mostly robust to sample selection, although the estimate is less precise for the CBEEE sub-sample in science.

\section{Subject Matter}

The coefficient estimates on subject matter are mostly negative in the sub-sample models; however, they lack the statistical significance that was present in the full sample. Thus, it may be that the presence of curriculum based external exit exams and unobservable factors in OECD 
countries diminish the impact of teachers holding influence over subject matter.

\section{Textbook}

The coefficient estimates on the dummy for teachers having a large influence on the choice of textbook are positive and statistically significant in the OECD sub-sample models using OLS for both subjects and using fixed effects in science. Both models result in positive coefficients with the CBEEE sub-sample for science, but negative coefficients for this sub-sample in math. It appears that the effects of giving teachers a large influence over the textbook is largely dependent on subject, whether or not the country has curriculum based external exit exams and other unobservable factors in OECD countries.

Policy Implications: teachers should have a large influence over the kind of supplies and textbook used in science classes in OECD countries.

\subsubsection{Country Specifics}

\section{GDP Per Capita}

The coefficient estimate on a country's GDP per capita in science is negative and statistically significant using both models for the OECD sub-sample. This result could be due to the fact that OECD countries have higher GDP per capita in general, but clearly does not indicate that countries should try to lower their GDP per capita in an attempt to increase academic success. The remaining sub-sample estimates for GDP per capita are largely statistically insignificant and mostly uninteresting.

\section{Expenditures Per Student}

The variable measuring the level of expenditures per student in a country has negative coefficients in all of the sub-sample estimates using the fixed effects model; including the CBEEE sub-sample estimate in science, which is statistically significant. This is in contrast to the positive and statistically significant findings for the full sample. The OLS sub-sample results are all positive, while the fixed effects sub-sample results are all negative. Thus, it could be that more spending on education is beneficial to student achievement, but that this spending is often inefficient. This also shows that there may be unobservable factors in OECD countries and other important characteristics of some countries (e.g. the presence CBEEEs) that play an important role in educational production function modeling.

\section{CONCLUSION}

Increased student achievement has been linked to increased economic growth, and thus has become a primary objective for most developed countries. Unfortunately, researchers have found scant evidence of factors within the control of policymakers that can increase student achievement. In fact, significant increases in per pupil expenditures in the United States over recent decades have not lead to any discernible increases in student test scores over the same period. Following the work of Woessman [15] and Collier and Millimet [9], this paper seeks to further our knowledge of the effects of institutional characteristics that may not vary within the United States. The TIMSS 1999 dataset (a compilation of over 120,000 students from 28 countries) is analyzed to determine whether an indirect relationship exists between institutional arrangements and student test scores, via a relationship with educational efficiency.

This paper uses two different educational models; one, ordinary least squares, includes the institutional characteristics as variables that directly influence student achievement; the other, a fixed effects model, first estimates the level of efficiency in each school then estimates the relationship between the institutional characteristics and school efficiency. Differences in the coefficient estimates of institutional characteristics between the two models are minimal, but do exist. The coefficients on: schools holding the responsibility for hiring teachers and determining teachers' salaries, and teachers holding a large influence on money for supplies are all statistically significant in the fixed effects model, but not so in the OLS model for both math and science. The opposite, statistical significance in the OLS model, is true of teachers individually influencing the curriculum in both math and science. In none of these instances do the signs of the coefficients differ and hold statistical significance. Thus, differences do result from using the two models, but it is not clear which model is necessarily preferred. This analysis does provide robust estimates for some institutional arrangements with consistent coefficient estimates across both models in both subjects. Our results suggest that: both teachers and schools holding the responsibility for purchasing supplies, subject teachers holding a strong influence over the curriculum and teachers having a strong influence over the kind of supplies used in the classroom are all positively associated with student achievement and school efficiency. Teachers' unions and teachers holding a strong influence over the subject matter are both negatively associated with student achievement and school efficiency.

Our specification analysis using sub-samples of the full data suggest that there are important differences in OECD and non-OECD countries that are not attributable to observable institutional arrangements. Additionally, curriculum-based external exit exams (CBEEEs) appear to have an important impact not only on student achievement, but also on the relationship between institutional arrangements and student achievement. Similar to Woessman [26], we find differing relationships between some of our institutional arrangements and school efficiency (as well as student achievement) between countries with and without CBEEEs.

Despite the differences between our approach and Woessman's [15] approach, it is clear that institutional arrangements are significantly related to educational production. Consistent findings across Woessman [15], Collier and Millimet [9], and the current paper include: school autonomy in purchasing supplies has a positive relationship with student achievement and efficiency; and teachers' unions having a large influence on curriculum is associated with lower levels of student achievement and 
school efficiency. In fact, this paper finds that a large influence on curriculum by teachers' unions has a stronger negative association on school efficiency than any of the other institutional arrangements analyzed in this paper. Future research to determine the exact relationship between institutional arrangements and student achievement could provide more concrete answers for the contradictory evidence across the three studies mentioned above.

\section{ACKNOWLEDGEMENT}

Declared none.

\section{CONFLICT OF INTEREST}

Declared none.

\section{REFERENCES}

[1] Snyder TD, Dillow SA, Hoffman CM. Digest of Education Statistics 2007. Washington, DC 2008.

[2] Epple D, Romano R. Competition between private and public schools, vouchers and peer group effects. Am Econ Rev 1998; 88: 33-62.

[3] Hoxby CM. Are efficiency and equity in school finance substitutes or compliments? J Econ Perspect 1996; 10: 671-718.

[4] Hanushek EA. The failure of input-based schooling policies. Econ J 2003; 113: F64-F98.

[5] Betts JR. Does school quality matter? evidence from the national longitudinal survey of youth. Rev Econ Stats 1995; 77: 231-50.

[6] Hoxby CM. The effects of class size on student achievement: new evidence from population variation. Q J Econ 2000; 115: 1239-85.

[7] Ruggiero J. Efficiency of educational production: an analysis of New York school districts. Rev Econ Stats 1996; 78: 499-509.

[8] Cooper ST, Cohn E. Estimation of a frontier production function for the South Carolina educational process. Econ Educ Rev 1997; 16: 331-27.

[9] Collier TC, Millimet DL. Institutional arrangements in educational systems and student achievement: a cross-national analysis. Empirical Econ 2009; 37: 329-81.

[10] Duncombe WJ, Miner J, Ruggiero J. Empirical evaluation of bureaucratic models of inefficiency. Public Choice 1997; 93: 1-18.
[11] Case A, Deaton A. School inputs and educational outcomes in South Africa. Q J Econ 1999; 114: 1047-84.

[12] Angrist JD, Lavy V. Using Maimonides' Rule to estimate the effect of class size on scholastic achievement. Q J Econ 1999; 114: 53375.

[13] Hanushek EA, Kimko DD. Schooling, labor-force quality, and the growth of nations. Am Econ Rev 2000; 90: 1184-208

[14] Hanushek EA, Luque JA. Efficiency and equity in schools around the world. Econ Educ Rev 2003; 25: 481-502.

[15] Woessman L. Schooling resources, educational institutions and student performance: the international evidence. Oxford Bull Econ Stats 2003; 65: 117-70.

[16] Dustmann CN, Rajah N, van Soest A. Class size, education, and wages. Econ J 2003; 113: F99-F120.

[17] Schmidt P, Sickles R. Production frontiers and panel data. J Bus Econ Stat 1984; 4: 367-74.

[18] TIMSS 1999 User Guide for the International Database 2001.

[19] Bishop JH, Woessman L. Institutional effects in a simple model of educational production. Educ Econ 2004; 12: 17-38.

[20] Fuchs T, Woessman L. What accounts for international differences in student performance? A re-examination using PISA data. Empirical Econ 2007; 32: 433-64.

[21] Vegas E. School choice, student performance, and teacher and school characteristics: the Chilean case 2002.

[22] Bishop JH. The effect of national standards and curriculum-based exams on achievement. Papers and Proceedings of the Hundred and Fourth Annual Meeting of the American Economic Association. Am Econ Rev 1997; 87: 260-4.

[23] Woessman L. Central exit exams and student achievement: international evidence. In: Peterson PE, West MR, Eds. No child left behind? the politics and practice of school accountability. Washington: Brookings Institution Press 2002; pp. 292-23.

[24] Hoxby CM. How teachers' unions affect education production. Q J Econ 1996; 111: 671-718.

[25] Millimet DL, Collier TC. Efficiency in public schools: does competition matter? J Econometrics 2008; 145: p. 134-57.

[26] Woessman L. The effect heterogeneity of central exams: evidence from TIMSS, TIMSS-Repeat and PISA. Educ Econ 2005; 13(2): 143-69.

[27] Martin MO, Gregory KD, Stemler SE. TIMSS 1999 technical report: IEAs repeat of the third international mathematics and science study at the eighth grade. Chestnut Hill MA 2000.

(C) Trevor C. Collier; Licensee Bentham Open.

This is an open access article licensed under the terms of the Creative Commons Attribution Non-Commercial License (http://creativecommons.org/licenses/by$\mathrm{nc} / 3.0 /$ ) which permits unrestricted, non-commercial use, distribution and reproduction in any medium, provided the work is properly cited. 